\title{
An Unnatural History of the Sexes
}

\author{
Anne Stone
}

Dans "Une histoire non naturelle des sexes," Anne Stone explore la relation du corps avec ce qui est "non naturel," cette érotisation du moment où la chair rencontre ce qui n'est pas chair, le "lent grincement du métal au moment où le véhicule se restructure autour de mon corps." Tomber en amour est comme "être à l'aéroport," et cette image centrale évoque la démystification de l'amour romanesque avec laquelle le texte est concerné. La banalité du quotidien - achetéunevoiture usagée, un chalet dans les Laurentides - succombe au leurre de la luxure: "Elle va dormir tout enétant debout devant des rideaux dorés, et rêver de lèvres rouge-sang sous la peau de la permission." Une lutte s'ensuit pour connaître les enjeux de l' "histoire": qu'est-ce qui constitue une histoire des sexes et qu'est-ce qui est si "naturel" à propos du sexe?

I was in love and it was like being at the airport. Each second articulated itself clearly, like a joint snapping into place. Minutes were not measured in litres. Time neither swelled over me nor collected just under the knee. My breasts were two janus eye-slits which revealed the month and the name of the day.

Time became a fluid measure after the wreck. Insinuating itself into teaspoons, pooling in my eyes, so that everywhere I looked I saw and tasted it quietly slipping away.

I could hear the slow grind of metal as the vehicle reshaped itself around my body. Hips thrust back, I waited for Time to plunge into me like a shipwreck, depress, like a hypodermic syringe. Later, I could pick over the remains, find something to sustain that lick of salt water against the thigh. Time bound my ankles and up-ended me, and the water lapped against my thighs. 
II apologize in advance for purchasing your cheap attention at the cost of good taste and credibility - but this is the part in which the storyteller is lithe, sliding an ankle behind her neck, she ushers you seamlessly forward. Watching the perambulations of her plastic limbs, you suspend disbelief entirely.]

I said: I was in love and it was like being at the airport. The stranger tells me he is buying a used car from the Baron Werner von Braun. The Baron wears spectacles and drives with his hand on the base of the steering wheel. I tell him that the Baron and I had a torrential love affair, in which I refused to take his sex into my mouth, and he used me like a twelve-yearold boy. The stranger smiles into his espresso.

I take the stranger to the place where the Baron and I played billiards. When lightning struck, Werner was carving a geometric figure on the skin of my nape, reducing the complexity of our lives to the mechanics of billiard balls.

Just how it happened, I tell the stranger, nobody knows. When lightning strikes, it sometimes engraves a photographic likeness into the window pane. Werner and I reduced to a chemical process, our two-dimensional image embedded in glass.

But the lightning was distant and struck some place else, igniting some other pair to panic, a clumsy beating back of flames, or a kiss.

Of Werner and me, it would take no more than the thinnest veneer.

The stranger invites me to the Baron's Chalet in the Laurentians. He says he needs a driver for the second car. I consult the map frequently, and the stranger begins to doubt I've ever known a Baron, let alone the Baron Werner von Braun. When we pull up, the Baron will be removing the siren and diplomatic plates from his slightly used car. The Baron's hair will be lovely and thick and fall just below his nipples. 
I am writing an erotic story in which you figure, I will tell him. In the story you have a lovely, oversize sex.

The heroine - that would be me, must bleed you in order for you to reach orgasm. Otherwise, your sex simply swells until it pains you and recedes like the sea.

Precisely how painful? he will ask.

The Baron will tip his chair against the bedroom wall, teaching me of the pleasures of the blade. He tells me that if I no longer associate it with asylums and slaughter, it will become quite another thing altogether.

He will dream a fist of Opium, clenching his hand, as I think of the loose rags of tea, soaked through and cupped in the cold tin scrying ball.

The Baron will finger his blade and ask if I love him.

As meat loves salt, I'll answer. Because that is how he will have taught me to answer.

The Baron often sits behind a Japanese screen. Past and future tenses flicker, rendering the blade and his sex indistinguishable. I can feel how cold the blade will be, warming in me, how cold his sex will be, warming in me, and how much colder I was, with all that warm stricken out.

The Baron's eyes are hyaline blue. He is an ambient figure, white noise. The quotient of a crowd.

Behind the screen, the Baron weeps until his eyelashes are worn away. 
I said: I was in love and it was like being at the airport. The stranger tells me he is buying a used car from the love-child of the Baron Werner von Braun. When she was still a girl, and her breasts offered up similes as meagre as the pits of fruit, the Baron sang her lullabies, splitting infinitives as carelessly as atoms.

She moves with uncanny grace, at once moth-like and implacable.

I tell the stranger that I once had a torrential love affair with the Baron's love-child, a showgirl from Vegas; that in the peacock-architexture of her dress were shoulder blades that spanned the sky.

When we arrive, the dancer will be pleating her hips with impatience. Her slightest touch will leave me trembling.

Her fingertips will find my elbow, steady me; assure me that there is a physical analog to experience, a shell to contain this shellfish brain.

Tabby walls, they call it, the husked oyster shells heaped high by the ocean, mortared together into walls; hard cold lips prying out of the mortar. Only ruins, now. Four foot high, in places, and thick as a man's shoulders, laid flat.

She will sleep while standing before gold velvet curtains, dream of the liver-red labia lying under the skin of persimmon. I will think only of my tongue, the small fissures of flesh that want salt; the ghostly scent of her on my arms.

She will give me a filmy scarf, to bind my wrists.

I'll bind my throat instead.

She will lift skirt to thigh and lean over me, pressing her thumb into the swell - leaving something to mark her passing, or maybe just marking Time. 
When she wakes, she'll light two gauloises, and we'll sit cross-legged on the floor. We'll hold lit cigarettes to the other's wrist, seeing who will flinch. It will be a slow game and demand absolute concentration. The stranger will pause as he passes and find no response.

She will smile without moving her lips, and say, my ancestors perished in flames. I am accustomed to the sensation of third-degree burns. I will tell her that my stories raise blisters on the lips of sleeping children. I want to feel the ember nest in my wrist like a fledgling bird.

But do you love me? she asks, as meat loves salt?

I said: I was in love and it was like being at the airport. The stranger tells me he is buying a used car from the love-child of the Baron Werner von Braun. I tell the stranger that I myself was a love-child, born in a fit of terror and weeping.

I tell the stranger that I had once been the love-child of Harold Agnew, who flew on an instrument plane, eyes trained on the Enola Gay. I was the love child of the man who took snap shots of the a-bomb as it plummeted towards Hiroshima.

Father later wondered aloud whether Time was a fluid medium, or snapshots scattered at his feet - a discrete sequence of frames. His fingers lingered over certain of those frames, as though by sleight of hand, he could disappear history.

Father was always taking pictures. His eyes burned like twin flash cubes, drilled shot holes in plant leaves, raised quivers on the seismographic flesh.

$* * *$

But then, I tell the stranger, Father wasn't like other men.... 
The stranger points to the Laurentians in the distance. As the sun bleeds down, they take on the appearance of the Sangre de Christo mountains. A fleshy darkness presses down and consumes them.

All at once I can hear the slow grind of metal as the vehicle reshapes itself around my body and I think of love. The car jerks to a stop, injecting a stream of light into the skin of darkness. The stranger smiles and tells me that he is in love and it's like being in a car wreck - that a car wreck is intoxicating precisely because it is unstoppable.

His fingers search my face, looking for contusions, abrasions, a smile or scar. I smell his fingers and they are like oranges. His hand clasps and unclasps my hair in a gesture that undoes itself. He measures my body according to the system of anthropometry, and I become the sky to Galileo. He traces the sockets of my eyes with his fingers and shapes himself to me.

I abandon my island body, and am touched. As touched as any village idiot, struck dumb. Like horses. Like rain.

The stranger tells me that he is in love and it is like my heart, if just once it could be laid bare. 